\title{
A büntetőhatalom mint végső eszköz egykor és most
}

\section{AMBERG ERZSÉBET}

A tanulmány „A büntetőjogi felelősség helye és ultima ratio szerepe a felelösségi alakzatok rendszerében" cím alatt folytatott doktori kutatási anyag egyes fejezeteiről nyújt áttekintést. A büntetőhatalom aktuális szerepfelfogásának megközelitéséhez látnunk kell, hogy milyen, illetve mekkora szerepet töltött be a társadalomirányitásban az ösközösségek kialakulásától kezdve napjainkig. Az összehasonlitó és történeti kontextusban szövegempirikus módszerrel végzett kutatás célja, hogy azonositsa a büntetöhatalom felfogásának fejlödési folyamatában a büntetőjog mint a társadalomirányitás végső eszköze - párhuzamosan a büntetőhatalom korlátozásának igénye - felfogás eszmei gyökereit. Megállapitható, hogy ez a megközelitési mód a felvilágosodás idöszakában jelent meg elsődlegesen jogi garanciák képében. A büntetőhatalom végsö eszközként történő igénybevételének igénye azonban nem érvényesült maradéktalanul az idők során, így tiszteletben tartása a jelen jogrendszerekben is hangsúlyozandó kívánalomként van jelen.

Kulcsszavak: büntetőhatalom, ultima ratio, büntetőjogi felelősség, büntetőjogi garanciák, társadalomirányítás

\section{Punitive Power as a Last Resort (Ultima Ratio) in Historical Aspect}

The study introduces briefly the historical and comparative aspects of a doctoral research entitled The Position and Last Resort Role of Criminal Responsibility in the System of Legal Responsibility Forms. In order to approach the current concept of the role of punitive power, we have to see what role criminal law has played in social governance, from the beginning of the human communities to the present day. The aim of the exploration, which uses the methodology of textual research in comparative and historical context, is to identify within the evolutionary process of criminal law perception the ideological roots of the need to limit punitive power, respectively the concept of criminal law as last resort. It can be stated that this approach appeared primarily in the form of legal guarantees during the Enlightenment period. However, the need to use criminal law as a final tool has not been fully realised over time, so its necessity has to be emphasised in the legal systems of nowadays.

Keywords: punitive power, last resort (ultima ratio), criminal liability, criminal law guarantees, social governance 


\section{Bevezetés}

Az ultima ratio latin eredetű kifejezés. Köznapi jelentése tükörfordításban végső eszköz, végső megoldás, végső érv. ${ }^{1}$ A büntetőjog mint végső eszköz követelménye egyértelműnek tünhet, azonosítva ezt a kritériumot a büntetőjog, a büntetőhatalom visszaszorítására irányuló igényként. A kérdéskör megközelítése mégis több irányba ágazik szét, amint magát a büntetőjogot is más-más aspektusokból közelítették meg a történelem során, ahogyan aktuálisan is eltérő fókuszpontú felfogásai ismertek. A kérdés a jelen kutatásban az, hogy - a büntetés jogának kialakításával párhuzamosan - a büntetés végső eszközként történő alkalmazásának igénye megformálódik-e, $\mathrm{s}$ ha igen, mely történelmi korszakokban és miként?

\section{A végső eszköz jellegü büntetőjog-koncepció történeti formái}

A bủncselekmény és a büntetés gondolata kezdetben vélhetően a maga gyakorlatias, ősi megjelenési formájában foglalkoztatta az emberiséget. A büntetőjog előtörténete és korai története során a büntetés enyhülésének több hulláma is megmutatta magát, kezdetben leginkább praktikus formában. Ekként vehető számba például a bosszú szelídülése a talio és a compositio elveinek megjelenésével, a testfenyítő és halálbüntetések körének csökkentése a kánonjogi nézetek, később a humanizáció jegyében, majd a halálbüntetés eltörlése. Mindezen tendenciák tartalmilag ugyan a büntetőhatalom korlátozását mutatják, lényegileg azonban távolról rokoníthatók csupán napjaink ultima ratio jellegű büntetőjog-felfogásával.

\section{A felvilágosodás mint a büntetőhatalom korlátozásának bölcsője}

A büntetőjog mint végső eszköz gondolatának megjelenése szorosabban a felvilágosodás korszakához köthető. ${ }^{2}$ Az európai büntető joggyakorlatra a 10-11. századtól az elrettentés elve és eszközrendszere volt jellemző, amelynek abszolút határozott, kegyetlen büntetési rendszere volt a halálbüntetést fő büntetési nemként tételezve. Mindez a központi hatalom megerősödésének, az állami büntetőjogi igény érvényesíthetővé válásának következményeként jelent meg. ${ }^{3} \mathrm{~A}$ feudális viszonyok tarthatatlanságának felismerése és bizonyos történelmi-társadalmi szükségszerüségek jogegységesítésre - a szokásjogi és a törvényi előírások rendszerbe foglalására, a jogi partikularizmus korlátozására, a központi bíráskodás intézményének erősítésére, az egységes jogalkalmazói gyakorlat kialakítására - irányuló igényeket váltottak ki a kontinensen. ${ }^{4}$

1 Lásd például: Latin-magyar szótár.

2 Erre a következtetésre jutott kutatásában például Marcus Dubber, Sakari Melander, Young Cheol Yoon és Malcolm Thorburn is. Vö.: Dubber, 2013, 1.; Yoon 2001, 7-9., 20-21.; Melander 2013, 45.; ThORBURN 2011, 85.

3 Vö.: BLASKó 2016, 30.

4 Vö.: BLASKó 2016, 31. 
A felvilágosodás individualista eszmeáramlata lényegében tehát olyan államrendszer - büntetőjog - kiépítésére törekedett, amelynek célja az államhatalom korlátozása az egyéni szabadság biztosítása érdekében. ${ }^{5}$

Montesquieu felismerte, hogy egy államban sohasem a többé vagy kevésbé kegyetlen büntetések miatt engedelmeskednek a törvényeknek, emiatt hangsúlyozta a büncselekmény és a büntetés arányosságának követelményét. ${ }^{6}$ Beccaria a bünmegelőzés jelentőségének, valamint az arányos büntetésnek a hangsúlyozása mellett rámutatott, hogy a bűncselekmények hatásos akadálya a büntetések elkerülhetetlensége, nem pedig a büntetés kegyetlensége. ${ }^{7}$ Hegel egy újabb lépéssel közelített a büntetöjog mai felfogásához azáltal, hogy a büntettest nem az állam büntetö hatalmának tárgyaként, hanem jogok alanyaként, méltósággal rendelkező személyként tekintette, aki igényt formálhatott az állami hatalommal szemben, személyes szabadságjogait illetően bizonyos garanciák elismerésére. ${ }^{8} \mathrm{~A}$ fenti felismerések hozzájárultak a társadalmi szabályozórendszerek 18-19. századi átalakulásához, párhuzamosan a modern értelemben vett büntetőjog kialakulásához. A folyamat együtt járt a szuverenitásból és a társadalmi szerződés doktrínájából fakadó, elvileg korlátlan állami büntetőhatalom (ius puniendi) keretek közé szoritását szolgáló alapelvek - így a jogbiztonságban megtestesülő jogállamiság és a humanitás eszméje - kialakításához, fokozatos érvényesüléséhez. ${ }^{9}$

\section{A hazai modern polgári büntetőjog kialakulásának időszaka}

A fenti eszmék hazai interpretációja támogatta a modern polgári jogelmélet kialakulását Magyarországon, amelynek fókuszába a jog eszközjellege került, célja a hatékony társadalomirányitás volt. ${ }^{10} \mathrm{~A}$ büntetőjog végső eszköz jellegére irányuló igények ebben a korszakban hazánkban alapvetően az írott büntető törvények megalkotásában, a büntetés mértékének arányosságában, a bűnelkövető mint a büntetőeljárás jogalanya emberi jogainak felismerésében mutatkoztak meg, amely gondolatok visszhangozása számos szerzőnél olvasható.

Szibenliszt Mihály az alapjogokat tisztelő ius puniendi felfogása, ${ }^{11}$ Szemere Bertalannak a büntetés szükséges és igazságos mértékre szorítására irányuló felhívása jól mutatta a büntetőhatalom féken tartására irányuló korabeli elképzeléseket. ${ }^{12}$ A büntetőhatalom végső eszköz jellegének gondolata hasonlóképpen felmerül Forster Károlynál. ${ }^{13}$

\footnotetext{
Vö.: IRK 1938, 3-4.

MONTESQUieu 1955, 148.

HORVÁTH 1981, 47-48.

HORVÁTH 1981, 58-59.

Vö.: KARSAI 2015, 41.

0 Vö.: BÁRdos 1988, 271.

11 Vö.: Petrasovszky 2005, 209., 212.

12 Vö.: SZEMERE 1841, 25.

13 Vö.: Forster 1874, 55.
} 
A 20. század elején Somló Bódog felfogásában szintúgy hangsúlyos volt a büntetőjog végső eszközként történő igénybevételének követelménye. ${ }^{14}$ Pikler Gyula a büntetés gyakorlati főelvei közé sorolta a legkisebb büntetés és annak korlátozott alkalmazása követelményeket. ${ }^{15}$ Vámbéry Rusztem a büntetőjogot az állami hatalom önkorlátozásaként fogta fel a társadalmi csoportok hatalmi viszonyainak megfelelő kompromisszum alapján azzal, hogy a büntetés jogáról egészében lemondani nem lehet. ${ }^{16}$ Angyal Pál a büntetőjog felelősségrendszerének szubszidiárius, a közjogi és magánjogi felelősségi formákat kiegészítő jellegét hangsúlyozta. ${ }^{17}$ Hacker Ervin óvott a büntetések célszerűségi határon túli, illetve túl gyakori alkalmazásától. ${ }^{18}$ Finkey Ferenc a büntetőjogot a társadalmi önvédelem rendszerének csupán egyik eszközeként jelölte meg a megelőzési intézkedések, a népjóléti és társadalomnevelési intézmények láncolata mellett. ${ }^{19}$

\section{Büntetőhatalom-felfogás a szocializmusban}

A szocializmus időszakát organisztikus-etetista alkotmányfilozófiával lehet jellemezni, amely az állam és a szervezett élet más formáinak elsődlegességét vallotta az egyénnel szemben, az alkotmányt tulajdonképpen a társadalomba való beavatkozás megalapozásának eszközeként, nem az emberi jogok védelmét garantáló instrumentumként vette figyelembe. ${ }^{20}$ Tényleges büntetőjogi rendszerünkben, a korszakban paternalista intervencionizmus uralkodott, amelynek megnyilvánulási formái a büntetőjogi tilalmak inflálódása és a prevenciós büntetésfelfogás voltak. Ez a büntetésideológia történelmileg egybecsengett a nyugati szociális-jóléti államok 1960-70-es években elterjedt kezeléselméletével. ${ }^{21} \mathrm{~A}$ fenti eszméknek megfelelően arra a következtetésre juthatunk, hogy a büntetöhatalom korlátozására igény artikulációja nem volt jellemzó a korszakban.

Az úgynevezett szocialista Btk. kommentárirodalma alapján emellett megjelent az a büntetőjog-felfogás, miszerint a büntetőjogi kényszerelem mellett egyre jelentősebb a meggyőzési elem - azaz más jogágak preventív jellegü szabályaival való operálás - szerepe a bűnözés elleni küzdelemben. ${ }^{22} \mathrm{~A}$ koncepció rámutat emellett, hogy a szocialista büntetőpolitika hosszú történelmi fejlődés során kialakult elve a különösen súlyos cselekmények büntetőjogi üldözése, illetve igazságos, egyúttal méltányos mértékü büntetéssel fenyegetése. ${ }^{23} \mathrm{~A}$ büntetőhatalom efféle moderálása

\footnotetext{
14 Vö.: SOMLÓ 1906, 25., 87., 107-108.

15 Vö.: PiKLER 1910, 123-125.; PiKLER 1897, 253.

16 VÁMBÉRY 1913, 38-39.

17 Angyal 1920, 2.

18 HACKER 1924, 34.

19 FINKEY 1933, 312.

20 Vö.: Paczolay 2003, 9-10.

21 SzABó 1992, 557.

22 KÁdÁr 1968, 20.

23 KÁDÁR 1968, 21.
} 
a gazdálkodási kötelességeket sértő büncselekmények szabályozási koncepciójában jelent meg legszembetűnőbben. Összességében arra a következtetésre juthatunk tehát, hogy a büntetöhatalom korlátozására irányuló igény kifejezödése részlegesen volt jellemző a korszakban.

\section{Posztmodern felfogások}

Az 1990-es években világszerte egyre több szerző emelte fel hangját a büntetőjog túlburjánzásával szemben. Így Herzog, aki szerint a társadalmi kockázatok megelözése érdekében kriminalizált magatartástípusok megbontják a büntetőjog hagyományos kötődését a tett büntetőjog jogállami koncepciójához, illetve a tettes büntetőjog reaktív koncepciójához. Szakítva ezekkel a klasszikus alapvetésekkel, a büntetőjog kiterjedhet a veszélyeztető típusú helyzetek teljes körü szankcionálására, amely az erőszak eszközeivel vezet egy biztonságos jóléti állam kialakításához. A fenti tendencia elleni egyik fékként nevesíti az ultima ratio értelemben vett büntetőjogi követelményét. ${ }^{24}$ A büntetőhatalom korlátozásának igénye számos német szerzőnél megfogalmazódik, olvasható például Hassemernél, ${ }^{25}$ Nauckénél, ${ }^{26}$ Lüdersennél, ${ }^{27}$ Prittwitznél. ${ }^{28}$ Az ultima ratio elvének monografikus értelmezése szintén a német büntető jogtudomány terméke, Yoon munkásságához köthető. A szerző álláspontja szerint az ultima ratio elve a büntetöhatalmat generális értelemben, emellett a büncselekmények körének meghatározása szempontjából is korlátozza. Utóbbi kontextusban az ultima ratio elve kétféle korlátot fejez ki, amelyek érvényesülésére Yoon olvasatában bizonyos normatív és empirikus bizonyítékok, próbakövek (Prüfsteine) alapján következtethetünk. ${ }^{29} \mathrm{Az}$ elv kvantitatív aspektusból a büntetést érdemlő magatartások körét korlátozza, érvényesülése a jogtárgysérelem, a társadalomellenesség, a normavilágosság, illetőleg a tényállás körülhatároltságának (Tatbestandsbestimmheit) vizsgálata alapján értékelhető. ${ }^{30} \mathrm{Az}$ ultima ratio elve kvalitatív korlátként áll fenn a szankcióval fenyegetés mértéke vonatkozásában, ${ }^{31}$ amelynek érvényesülését a bűnfelelősség elve, a büntetőjog szubszidiárius jellege (fragmentaritása), az eszköz-cél arányosságának követelménye, a tettarányosság kritériuma, illetve a szankciók meghatározottságának követelménye közvetíti. ${ }^{32}$

Maria Kaiafa-Gbandi az ultima ratio elvének német interpretációját alapul véve elismeri az ultima ratio elvének szoros kapcsolatát az arányosság követelményével. Különbségüket abban ragadja meg, hogy míg az arányosság kritériuma esetén magát

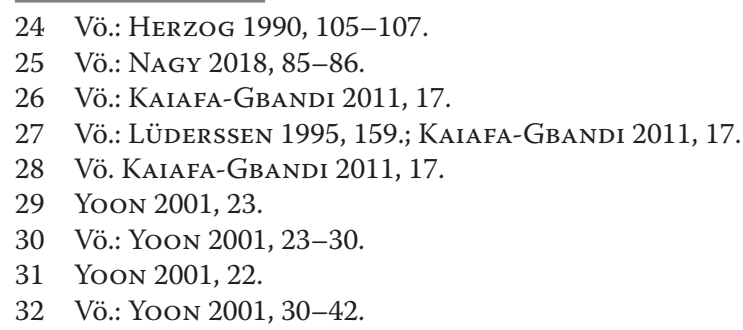


a beavatkozás célját nem, pusztán annak jogkövetkezményét értékeljük, addig az ultima ratio követelménye (végső érv kivételes esetben), tekintve, hogy kvantitatív és kvalitatív korlátokat egyaránt kifejező elv, a jogkorlátozási cél értékelése körében is alkalmazható. ${ }^{33}$

Nils Jareborg a kriminalizáció mint végső megoldás ideáját nem alkotmányos elvként, inkább egy mellözött jogalkotás-etikai elvként kategorizálja, amely a büntetőjog szubszidiaritásához, valamint fragmentális jellegéhez kötődik, azonositható a prospektív tettarányossággal, ezáltal önálló normatív funkciója nincs. Az ultima ratio jelentőséghez úgy juthat, ha a kriminalizáció elveinek - a büntetési érték (blameworthyness), a hasznosság (utility) és a humanitás (humanity) elve - gyüjtőelveként tekintünk rá. Az ultima ratio üzenete gyüjtőelv minőségét, funkcióját tekintve kettős. Magas büntetési érték esetén pro-kriminalizációs felhívás, míg alacsony büntetési érték esetén kontra-kriminalizációs korlát, a hasznossági és humanitási szempontok határozottabb figyelembevételére irányuló felszólítás képében jelenik meg. ${ }^{34}$

A büntetőhatalom korlátozására irányuló igény angolszász jogterületen is felmerült, így például Walkernél, ${ }^{35}$ Ashworth-nél, ${ }^{36}$ és Schonscheknél. ${ }^{37} \mathrm{~A}$ büntetőjog végső védőháló (last resort) jellege Husak interpretációjában a kriminalizáció elméletének részeként jelenik meg, azonban önmagában nem oldja meg a büntetőjogi szabályozás kiszélesedésének problémáját anélkül, hogy a bűnről és büntetésről vallott hagyományos szemléletben ne következne be változás (paradigmaváltás). ${ }^{38}$ Hazai viszonylatban a szegedi büntetőjogi műhely képviselői foglalkoznak legintenzívebben a büntetőjog mint végső eszköz értelmezési kérdéseivel. ${ }^{39}$

\section{Összefoglalás}

Az ultima ratio elv értelmezésének történeti és összehasonlító vizsgálata alapján elmondható, hogy az a büntetendővé nyilvánítás hermeneutikus előkérdéseként, értelmezési bázisaként fogható fel, leginkább mint kapcsolódó elvek konstellációja. Az elv a büntetőjog kulturális örökségének része, amely jogerkölcsi vagy politikaerkölcsi elvként jellemezhető, feltételezhetően a túlzott kriminalizáció elleni beépített fék. Értelmezése körében számos nyitott kérdés merül fel, így vitatott az alkotmányos rangú alapelvi minősége, egyfajta politikaikövetelmény-jellege, illetve speciális jogalkotás-etikát befolyásoló minösége. Bizonytalanság mutatkozik abban a kérdésben is, hogy az elv vajon a büntetőjog és más jogágak által szankcionált magatartások közötti speciális kvalitatív különbséget jelöli-e $?^{40}$ A fenti elméleti bizonytalanságok mind

33 KAIAFA-GBANDi 2011, 17.

34 JAREBORG 2005, 521., 525., 531-532.

35 Vö.: Walker 1994, 459.

36 Vö.: KARSAi 2015, 79.; Vö.: Ashworth 1999, 67-68.

37 Vö.: SCHONSHECK 1994, 64-70.

38 Husak 2004, 208.

39 Így például: NAGY 2014, 361-370.; KARSAI 2012, 253-260.

40 Bengoetxea-Jung-Nuotio 2013, 3-4. 
nemzetközi, mind hazai viszonylatban fennállnak. ${ }^{41}$ A büntetőjog mint ultima ratio értelmezése körül előrelépés abban látható, hogy fokozott tudományos érdeklődés övezi ezt a koncepciót, amelybe jelen tanulmány csupán bepillantást engedhetett a terjedelmi korlátok tisztelete mellett. ${ }^{42}$

\section{Felhasznált irodalom}

Amberg Erzsébet (2012): Büntetőjogi ultima ratio? Magyar Rendészet, 12. évf. 4. sz. 41-47.

ANGYal Pál (1920): A magyar büntetőjog tankönyve. Budapest, Athenaeum.

Ashworth, Andrew (1999): Principles Of Criminal Law. 3d ed. Oxford, Oxford University Press.

BÁrdos Péter (1988): Megjegyzések a jog módszertanához. Jogtudományi Közlöny, 43. évf. 5. sz. 269-272.

Bengoetxea, Joxerramon - Jung, Heike - Nuotio, Kimmo (2013): Ultima Ratio, is the Principle at Risk?: Editors' Introduction. Oñati Socio-legal Series, Vol. 3, No. 1, 1-5. Elérhető: https://ssrn. com/abstract=2213166 (2020. 03. 25.)

Blaskó Béla (2016): Magyar Büntetőjog Általános Rész. Tankönyv. Hatodik, átdolgozott és bővített kiadás, Budapest-Debrecen, Rejtjel Kiadó.

Dubber, Markus D. (2013): Ultima Ratio as Caveat Dominus: Legal Principles, Police Maxims, and the Critical Analysis of Law. SSRN Electronic Journal. DOI: https://doi.org/10.2139/ ssrn. 2289479

Finkey Ferenc (1933): Büntetéstani problémák. Budapest, A Magyar Tudományos Akadémia Jogtudományi Bizottságának Kiadványsorozata, 4. sz.

Forster Károly (1874): Jog, politika és bölcsészet. 1. rész. Budapest, Zilahy Sámuel Bizománya.

HaCKer Ervin (1924): Bevezetés a büntetőjog bölcseletébe. Pécs, Dunántúl Könyvkiadó és Nyomda r-t.

Herzog, Felix (1990): Nullum crimen sine lege periculo sociali. Strafrecht als Fortsetzung der Sozialpolitik mit anderen Mitteln. - Vier Skizzen. In Lüderssen, Klaus - Nestler, Cornelius - Weigend, Ewa hrsg.: Modernes Strafrecht und ultima-ratio-Prinzip. Frankfurter kriminalwissenschaftliche Studien. Frankfurt am Main - Bern - New York - Paris, Peter Lang.

Horváth Tibor (1981): A büntetési elméletek fejlödésének vázlata. Budapest, Akadémiai Kiadó.

Husak, Douglas (2004): The Criminal Law as Last Resort. Oxford Journal of Legal Studies, Vol. 24, No. 2, 207-235. DOI: https://doi.org/10.1093/ojls/24.2.207

IRK Albert (1933): Az individualizmus és kollektivizmus gondolatköre a büntetőjogban. Pécs, Szent István Akadémia.

IRK Albert (1938): A büntetőjog racionális és irracionális elemei. Székfoglaló értekezés. In LUKINICH Imre szerk: Értekezések a filozófia és a társadalomtudományok köréböl, 5. köt. 4. sz. Budapest, Magyar Tudományos Akadémia.

JAREBorg, Nils (2005): Criminalisation as Last Resort (Ultima Ratio). Ohio State Journal of Criminal Law, Vol. 2, No. 2, 521-534.

Kaiafa-Gbandi, Maria (2011): The Importance of Core Principles of Substantive Criminal Law for a European Criminal Policy Respecting Fundamental Rights and the Rule of Law. European Criminal Law Review, Vol. 1, No. 1, 6-33. DOI: https://doi.org/10.5235/219174411798862640

41 Vö.: Amberg 2012, 45-47.

42 Az ultima ratio jellegü büntetőjog értelmezéséről bővebb információ áll rendelkezésre a szerző további publikációiban. 
KARSAI Krisztina (2012): Az ultima ratio elvéről - másképpen. In JuHÁsz Zsuzsanna - NaGY Ferenc - FAntoly Zsanett szerk.: Sapienti sat: ünnepi kötet Dr. Cséka Ervin professzor 90. születésnapjára. Szeged, Szegedi Tudományegyetem Állam- és Jogtudományi Kar. 253-260.

KARSAI Krisztina (2015): Az alapelvek rendszere az európai büntetőjogban. MTA doktori értekezés, Szeged.

KÁDÁr Miklós (1968): A büntető törvény feladata. In HaLÁsz Sándor szerk.: A büntető törvénykönyv kommentárja. Budapest, Közigazgatási és Jogi Könyvkiadó.

Latin-magyar szótár. Elérhető: https://dictzone.com/latin-magyar-szotar/ultima\%20ratio (2020. 03. 25.)

LÜDERSSEN, Klaus (1995): Notwehrelemente in der Strafe-Strafelemente in der Notwehr. Ein vitiöser Zirkel oder Quelle neuer Einsichten in den Anachronismus der Strafe? In Institut für Kriminalwissenschaften Frankfurt/M (ed.) Vom unmöglichen Zustand des Strafrechts. Frankfurt am Main, Lang.

Melander, Sakari (2013): Ultima ratio in European Criminal Law. European Criminal Law Review, Vol. 3, No. 1, 45-64. DOI: https://doi.org/10.5235/219174413806915441

Montesquieu, Charles-Louis (1955) [1721]: Perzsa levelek. Budapest, Új Magyar Könyvkiadó.

NAGY Ferenc (2014): Új tendenciák a büntetőjogban. Búcsú a büntetőjog ultima ratio jellegétől. In Borbíró Andrea - Inzelt Éva - Kerezsi Klára - LÉvay Miklós - Pooletz Léna szerk.: A büntetőhatalom korlátainak megtartása: a büntetés mint végső eszköz. Tanulmányok Gönczöl Katalin tiszteletére. Budapest, ELTE Eötvös Kiadó. 361-370.

NAGY Ferenc (2018): Az állami büntetőhatalom korlátozása ellen ható tendenciák a büntetőjogban. Állam-és Jogtudomány, 59. évf. 1. sz. 78-92.

Paczolay Péter (2003): Alkotmánybíráskodás a politika és jog határán. In SZABÓ Máté szerk.: Alkotmánybíráskodás - Alkotmányértelmezés. Rejtjel Kiadó, Budapest. 9-10.

Petrasovszky Anna (2005): Az állam büntetőjogi hatalma Szibenliszt Mihály művében. In Jámborné Róth Erika szerk.: Doktoranduszok fóruma 2005: Miskolc, 2005. november. 9.: Állam-és Jogtudományi Kar szekciókiadványa. 209-215.

PikLer Gyula (1897): A jog keletkezéséről. Budapest, Politzer Zsigmond Könyvkereskedő Kiadása.

PIKLER Gyula (1898): A büntetöjog bölcselete. 2. kiadás, Budapest, Politzer.

PIKLer Gyula (1910): A büntetőjog bölcselete. 7. javított kiadás, Budapest, Grill Károly Könyvkiadóvállalata.

SCHONSHeCK, Jonathan (1994): On Criminalization 1. Dordrecht, Springer. DOI: https://doi. org/10.1007/978-94-015-8100-4_1

Sólyom László (2001): Az alkotmánybíráskodás kezdetei Magyarországon, Budapest, Osiris Kiadó.

SomLó Bódog (1906): Somló Bódog jogbölcseleti előadásai. Második füzet. Kolozsvár, Sonnenfeld Adolf könyv- és műnyomdája.

SzABó András (1992): Büntetőjogi gondolkodásunk jelenlegi állása. Jogtudományi Közlöny, 47. évf. 11-12. sz. 555-557.

Szabó András (2004): Recepció és kreativitás a büntetőjogban. In SAJó András szerk: Befogadás és eredetiség a jogban és a jogtudományban. Budapest, Áron Kiadó.

Szemere Bertalan (1841): A büntetésről, s különösebben a halálbüntetésről. Buda.

Thorburn, Malcolm (2011): Constitutionalism and the Limits of the Criminal Law. In Duff, R. A. Farmer, Lindsey - Marshall, S. E. - Renzo, Massimo - Tadros, Victor eds.: The Structures of the Criminal Law. 85-105. DOI: https://doi.org/10.1093/acprof:oso/9780199644315.003.0005 
TuOrI, Kaarlo Heikki (2013): Ultima Ratio as a Constitutional Principle. Oñati Socio-legal Series, Vol. 3, No. 1, 6-20. Elérhető: http://ssrn.com/abstract=2200869 (2020. 03. 25.)

VÁmbÉRY Rusztem (1913): Büntetőjog. Budapest, Grill Károly Könyvkiadóvállalata.

WALKer, Nigel (1994): A büntetőjog alkalmazási köre. In HorvÁtH Tibor - SzüK László szerk.: Büntetöjogi szakirodalomgyüjtemény. Budapest, Nemzeti Tankönyvkiadó. 458-469.

Yoon, Young-Cheol (2001): Strafrecht als ultima ratio und Bestrafung von Unternehmen. Bécs, Peter Lang. 